\title{
Estimation of Genetic Parameters and Selection of Parents for Hybridization in Dolichos Bean [Dolichos lablab L.]
}

\section{Niharika Jyotirekha Nayak ${ }^{1}$, Praveen Kumar Maurya ${ }^{1}$, Anirban Maji², Soumitra Chatterjee $^{3}$, Amit Ranjan Mandal ${ }^{1}$ and Arup Chattopadhyay ${ }^{1 *}$}

${ }^{1}$ Department of Vegetable Science, Faculty of Horticulture, Bidhan Chandra Krishi Viswavidyalaya, Mohanpur-741252, Nadia, West Bengal, India

${ }^{2}$ Department of Genetics and Plant Breeding, ${ }^{3}$ Department of Agricultural Economics, Faculty of Agriculture, Bidhan Chandra Krishi Viswavidyalaya, Mohanpur-741252,

Nadia, West Bengal, India

*Corresponding author

\section{A B S T R A C T}

\begin{tabular}{|l|}
\hline K e y w o r d s \\
Dolichos bean, \\
Characterization, \\
Yield components, \\
Genetic divergence, \\
PCA.
\end{tabular}

Twenty three indeterminate genotypes of dolichos bean were evaluated for their genetic variability, character associationships and genetic divergence among ten quantitative traits. The study revealed significant variation in days to $50 \%$ flowering, pod length, pod width, pod thickness, pod weight, number of pods per plant, leaf width, raceme length and pod yield per plant. Days to $50 \%$ flowering, pod weight, number of pods per plant, pod width, pod thickness, pod length and pod yield per plant exhibited high GCV, PCV, heritability and genetic advance as percent of mean indicating that such situation might arise due to the action of additive genes controlling the characters. From study of character associationships, it revealed that the top priority should be given to selection based on the pod weight and number of pods per plant for pod yield improvement of dolichos bean. Based on the relative magnitude of $\mathrm{D}^{2}$ values, 23 genotypes could meaningfully be grouped into 2 clusters. Based on principal component analysis and average values, three genotypes 2016/DOLP VAR-9, BCDB-10 and 2016/DOLP VAR-4 appeared very promising candidates for utilization in breeding programme to develop improved lines of dolichos bean.

\section{Introduction}

Among vegetable legumes, dolichos bean [Dolichos lablab L.] is an important crop grown throughout India. The crop is primarily grown for green pods but its dry seeds are used for various vegetable preparations. Even foliage of the crop provides hay, silage and green manures. Wide variation exists in the plant and pod characters among the cultivars grown all over the country (Peter and Kumar, 2008). Still the crop is not gained desired importance from the breeders even though wide genetic base exists for breeding programmes (Upadhyay and Mehta, 2010). The reason could be severe competition by other competing crops with higher return on the one hand, and long duration, photosensitivity and indeterminate growth habit from other. Few concerted efforts have been made (Chattopadhyay and Dutta, 2010; Das et al., 2015) to collect and conserve 
available genetic resources for their utilization in breeding programme in the Gangetic plains of eastern India.

In spite of its high protein content, good acceptability among cultivators and consumers, and wide range of available genetic variability, India is still lagging behind to attain the optimum productivity in dolichos bean than other neibouring countries. Therefore, much concentrated efforts are necessary to improve its yield at present. Yield, being a complex trait, is collectively influenced by various component characters, which are polygenically inherited and highly influenced by environmental variations. Further, partitioning the variability into heritable and non-heritable components with suitable genetic parameters, such as, genotypic and phenotypic coefficient of variation; heritability estimates and genetic advance, cause and effect relations through phenotypic and genotypic correlations do help great deal to formulate selection strategies to develop suitable genotypes.

Knowledge of correlation between yield and its contributing characters are basic and for most endeavor to find out guidelines for plant selection. Partitioning of total correlation into direct and indirect effect by path coefficient analysis helps in making the selection more effective (Biju et al., 2001). The importance and extent of genetic divergence have been investigated in many crops but the information generated with dolichos bean is scanty. A successful hybridization programme for varietal improvement depends mainly on the selection of the parents having wide genetic divergence. Precise information on the nature and degree of genetic divergence would help the plant breeder in choosing promising parents for purposeful hybridization or heterosis breeding programmes. Multivariate analysis by means of Mahalanobis $\mathrm{D}^{2}$ statistic is a powerful tool in quantifying the divergence among genotypes. Therefore, present study was undertaken, employing 23 genotypes to analyze variability, relationship between yield components, association among desired traits, extent and nature of direct and indirect effects and divergence of yield contributing characters in dolichos bean.

\section{Materials and Methods}

The investigation was carried out at " $\mathrm{C}$ " Block Farm of Bidhan Chandra Krishi Viswavidyalaya, Kalyani, Nadia, West Bengal under the research field of All India Coordinated Research Project on Vegetable Crops, situated at $23.5^{\circ} \mathrm{N}$ latitude and $89^{\circ} \mathrm{E}$ longitude at a mean sea level of $9.75 \mathrm{~m}$ during autumn-winter season starting from August, 2015 to March, 2017. The soil texture of the farm is sandy loam having neutral in reaction. Twenty three genotypes of dolichos bean collected from different sources have been characterized on the basis of qualitative and quantitative characters as per documented descriptors. Seeds of twenty three pole type genotypes were sown in well-prepared field in separate plots measuring $4.5 \mathrm{~m} \times 4.5 \mathrm{~m}$ at 1.5 $\mathrm{m}$ spacing in both ways during the month of August, 2015 following Randomized Block Design with three replications. During active vegetative growth phase, all the six plants of pole type genotypes in each plot were supported with bamboo poles as trellis. The plots were fertilized with $30 \mathrm{~kg} \mathrm{~N}$ in the form of urea, $60 \mathrm{~kg} \mathrm{P}$ in the form of single super phosphate and $50 \mathrm{~kg} \mathrm{~K}$ in the form of muriate of potash. All the cultural practices and plant protection measures scheduled for its cultivation were followed in time as per Chattopadhyay et al., (2007). Observations from all six selected plants of each genotype in each replication were recorded on ten quantitative traits namely, days to $50 \%$ flowering, raceme length $(\mathrm{cm})$, leaf length $(\mathrm{cm})$, leaf diameter $(\mathrm{cm})$, pod length $(\mathrm{cm})$, 
pod diameter $(\mathrm{cm})$, pod thickness $(\mathrm{cm})$, number of pods per plant, pod weight $(\mathrm{g})$ and pod yield per plant $(\mathrm{kg})$.

Analysis of variance was performed following the standard procedures. The phenotypic and genotypic coefficients of variation (PCV and GCV) were estimated as per Burton (1952), Heritability in broad sense was estimated by the formula given by Hanson et al., (1956), and genetic advance as per Johnson et al., (1955) and Lush (1949). Path coefficient analysis was done according to formula given by Dewey and Lu (1959). Genetic diversity between genotypes was estimated by using $\mathrm{D}^{2}$ analysis given by Mahalanobis (1936). Grouping of the genotypes into various clusters was done by using Tocher's method as described by Rao (1952). Subsequently hierarchical cluster analysis was done with those same genotypes in order to observe the degree of association according to their characteristics that was expressed in dendrogram following Ward's (1963) method. Principal Component Analysis (PCA) was done using SAS 9.3 Professional Version and SPSS Professional Version 13.0.

\section{Results and Discussion}

\section{Mean performance of genotypes}

Twenty three genotypes collected from different sources were characterized on the basis of morphological characters as per documented NBPGR descriptors. Mean of the 10 characters of 23 dolichos bean genotypes were recorded and the study showed wide range of variations in most of the characters like days to $50 \%$ flowering, pod length, pod width, pod thickness, pod weight, number of pods per plant, leaf width, raceme length and pod yield per plant, showing the suitability of the genotypes for carrying out the study of genetic variability for these characters. However, not much variation could be recorded among the genotypes for the character leaf length, indicating comparatively lesser weightage of this character for such genetic variability study. Moreover, all the dolichos bean genotypes under study showed highly significant variations among the different characters (Table 1). The genotype BCDB-20 was the earliest to produce single flower in $50 \%$ plant population (50 days) followed by 2013/DOLB VAR-4 (54.67 days). The average range of leaf width in all the genotypes varied from $7.91 \mathrm{~cm}$ in BCDB-2 to $12.64 \mathrm{~cm}$ in BCDB-5. The maximum leaf length being in 2016/DOLP VAR-9 $(13.77 \mathrm{~cm})$, followed by 2013/DOLP VAR-8 $(13.78 \mathrm{~cm})$ and minimum in BCDB-2 $(8.35 \mathrm{~cm})$. The average raceme length was found to be the highest $(37.97 \mathrm{~cm})$ in 2014/DOLP VAR-3 followed by $36.50 \mathrm{~cm}$ in 2014/DOLP VAR-4 and the minimum was found in 2013/DOLP VAR- $3(4.97 \mathrm{~cm})$. So far as the pod length is concerned, the genotype 2016/DOLP VAR-9 produced the maximum average pod length $(21.49 \mathrm{~cm})$ followed by 2016/DOLP VAR-5 $(17.02 \mathrm{~cm})$, whereas the genotype 2014/DOLP VAR-3 produced the minimum $(5.59 \mathrm{~cm})$ pod length. The average range of pod diameter in all the genotypes varied from $0.96 \mathrm{~cm}$ in 2016/DOLP VAR-10 to $3.79 \mathrm{~cm}$ in BCDB10. The maximum pod weight being in 2016/DOLP VAR-9 (13.83 g) followed by BCDB-10 (13.66 g) and minimum in 2014/DOLP VAR-4 (4.02 g). The average number of pods per plant was found to be the highest in Swarna Utkrisht (1004.00) followed by BCDB-2 (976.00) and the lowest number were found in 2016/DOLP VAR-8 (238.00). The maximum pod thickness was found in 2013/DOLP VAR-1 (0.99 cm), followed by 2016/DOLP VAR-1 $(0.93 \mathrm{~cm})$ and the minimum in 2014/DOLP VAR-3 $(0.23 \mathrm{~cm})$. Pod yield per plant was also influenced significantly among the genotype, ranging from $1.59 \mathrm{~kg}$ to $12.43 \mathrm{~kg}$, the maximum being in 2016/DOLP VAR-9 
$(12.43 \mathrm{~kg})$ followed by BCDB-10 $(8.38 \mathrm{~kg})$ and minimum 2016/DOLP VAR-8 (1.59 kg).

\section{Study on genetic variability and heritability}

Success of any plant breeding programme is dependent on degree of genetic variability of the available germplasms. All these characters under study showed highly significant variation among the genotypes indicating their importance in the study of genetic variability. Estimates for the co-efficient of phenotypic and genotypic variation (PCV and GCV respectively), heritability in broad sense, and GA as \% of mean for these characters were presented in the Table 2 . The genotypic co-efficient of variation measures the range of genetic variability shown by the plant characters and helps to compare the genetic variability present in various characters (Sanghi et al., 1964). Close estimates of GCV and PCV were recorded for all the characters but the magnitude of PCV was higher than GCV for almost all the characters. Close estimates of GCV and PCV were also recorded for most of the characters by Ganesh (2005). It implies that contribution towards final phenotypic expression of these characters was mostly by genetic makeup of these varieties rather than the environmental factors. This suggested that selection could be effective on the basis of phenotypic characters alone with equal probability of success in these characters. For correct estimation of the genetic makeup and its contribution to phenotypic expression of the character, it is necessary that analysis of that character should be conducted in terms of different locations and different seasons. The highest GCV value was recorded for the character pod yield/plant $(51.82 \%)$ followed by pod weight (39.10\%) and the lowest value for leaf length (13.79\%). However, the range of PCV varied from $15.89 \%$ (leaf width) to $52.28 \%$ (pod yield/plant). In the present investigation all the characters except leaf length and leaf width exhibited very high GCV and this finding corroborates the earlier observations of Chattopadhyay and Dutta (2010), Das et al., (2015). This shows prevalence of greater genetic variability among the genotypes which offers good opportunities for crop improvement through selection.

High proportion of GCV to PCV is desirable in selection process because it depicts that the traits are much under the genetic control rather than the environment (Kaushik et al., 2007). The proportion of GCV and PCV observed in this study varied from $78.31 \%$ in leaf length to $99.94 \%$ in pod weight. Traits with high proportion of these values are reliable for selection in genetic improvement of crops. Trait whose expression is environmentally dependent may not be reliable descriptors for morphological characterization. However, in this study, the proportion of genetic contribution to the overall phenotypic expression of most of the traits was very high. Therefore, their use as important discriminatory variable for dolichos bean classification studies seems relatively reliable. The genetic co-efficient of variation is the measure to estimate the variability of the plant characters. However, with the help of genetic co-efficient of variation alone it is not possible to determine the amount of variation that is heritable. The heritable portion of the variation was determined with the aid of heritability estimates. The GCV $x$ selection differential, estimates the maximum effectiveness of selection and heritability indicates how closely the goal can be achieved (Singh et al., 1968).

In the present investigation very high broad sense heritability (more than $80 \%$ ) was recorded for most of the characters studied except leaf length, leaf width and raceme length. Above average to high heritability estimates $(60-80 \%)$ were recorded for leaf 
length, leaf width, raceme length. So, most of the characters under study showed above average to very high heritability. The high estimates of heritability in the quantitative characters has been found to be useful from plant breeders view point as this would enable him to base his selection on the phenotypic performance.

Improvement in the mean genotypic value of the selected families over the base population is known as genetic advance under selection and it depends upon the genetic variability, index of transmissibility i.e. heritability and intensity of selection, i.e. proportion of plants selected. In the present study keeping the selection differential constant 2.06 for 5\% selection intensity, GA was expressed as percentage of mean (Table 2). The genetic advance (GA) expressed as percentage of mean was high for all the characters studied. In other words, days to $50 \%$ flowering, pod weight, number of pods per plant, pod width, pod thickness, pod length and pod yield per plant were characterised by high heritability and high genetic advance.

According to Panse (1957), such characters are controlled by additive gene effects. The results find support from the observations of earlier workers (Borah and Shadeque, 1992; Uddin and Newaz, 1997). Johnson et al., (1955) had suggested that heritability estimates along with genetic gain is usually more helpful than the heritability alone in predicting the resultant effect for selecting best individuals. So these two genetic parameters must be considered together to predict the expected genetic progress possible through selection. Very high heritability coupled with very high GA was observed for days to $50 \%$ flowering, pod weight, number of pods per plant, pod width, pod thickness, pod length and pod yield per plant. These seven characters can be regarded as most important for selection because of probable control by additive gene action and this result was supported by the finding of Mohan et al., (2014) and Verma et al., (2015).

\section{Character associationships}

This statistics measure the mutual relationship between various plant characters and determines component characters on which selection can be based for improvement in yield. It might be easier to increase yield by increasing the smallest yield components on an otherwise good cultivar.

In general, the genotypic correlations were higher than the phenotypic ones, which indicated that the phenotypic expression of the correlation is reduced under the influence of environment, although there is a strong inherent association between the various characters. The results have been discussed here under on the basis of both phenotypic and genotypic correlations. Out of ten characters studied (Table 3 ), four characters namely, number of pods per plant $\left(\mathrm{r}=0.58^{* *}\right.$, $\left.0.59^{* *}\right)$, pod weight $\left(\mathrm{r}=0.74^{* *}, 0.74^{* *}\right)$, pod length $\left(\mathrm{r}=0.45^{*}, 0.42^{*}\right)$ and pod diameter $(\mathrm{r}=$ $\left.0.48^{*}, 0.45^{*}\right)$ exhibited significant positive correlations with pod yield per plant at both genotypic and phenotypic levels, respectively. Besides, the characters like pod thickness, leaf length and leaf width also showed positive but non-significant correlations with pod yield per plant. However, days to $50 \%$ flowering and raceme length exhibited negative correlation with pod yield per plant. This indicated that delay in first flowering in $50 \%$ population and lesser raceme length helped in improving pod yield per plant. The direct selection for number of pods per plant and pod weight could be beneficial for yield improvement of dolichos bean. The results are in conformity with the observations of Kabir and Sen (1987), Patil et al., (2011) and Chattopadhyay and Dutta (2010). 
Table.1 Mean performances of twenty three genotypes of dolichos bean

\begin{tabular}{|c|c|c|c|c|c|c|c|c|c|c|}
\hline Genotype & $\begin{array}{c}\text { Days to } \\
50 \% \\
\text { flowering }\end{array}$ & $\begin{array}{l}\text { Raceme } \\
\text { length }(\mathrm{cm})\end{array}$ & $\begin{array}{c}\text { Leaf } \\
\text { length } \\
(\mathrm{cm}) \\
\end{array}$ & $\begin{array}{l}\text { Leaf } \\
\text { width } \\
(\mathrm{cm})\end{array}$ & $\begin{array}{l}\text { Pod } \\
\text { length } \\
(\mathrm{cm}) \\
\end{array}$ & $\begin{array}{c}\text { Pod } \\
\text { diameter } \\
(\mathrm{cm})\end{array}$ & $\begin{array}{c}\text { Pod } \\
\text { thickness } \\
(\mathrm{cm})\end{array}$ & $\begin{array}{c}\text { Number of } \\
\text { pods per plant }\end{array}$ & $\begin{array}{c}\text { Pod } \\
\text { weight }(g)\end{array}$ & $\begin{array}{c}\text { Pod yield } \\
\text { per plant } \\
(\mathrm{kg})\end{array}$ \\
\hline 2013/DOLP VAR-1 & 88.33 & 16.90 & 12.13 & 9.93 & 10.92 & 1.66 & 0.99 & 656.00 & 10.30 & 6.77 \\
\hline 2013/DOLP VAR-2 & 97.33 & 24.55 & 13.63 & 11.37 & 11.22 & 1.31 & 0.60 & 850.00 & 5.79 & 4.92 \\
\hline 2013/DOLP VAR-3 & 100.67 & 4.97 & 10.33 & 8.27 & 12.96 & 2.01 & 0.37 & 674.00 & 7.00 & 4.73 \\
\hline 2013/DOLP VAR-4 & 54.67 & 23.77 & 10.00 & 8.73 & 12.37 & 1.94 & 0.86 & 831.00 & 6.30 & 5.23 \\
\hline 2014/DOLP VAR-1 & 81.33 & 29.63 & 10.40 & 9.13 & 11.92 & 2.09 & 0.39 & 773.00 & 5.53 & 4.27 \\
\hline 2014/DOLP VAR-2 & 77.33 & 22.60 & 9.77 & 9.03 & 11.27 & 1.80 & 0.38 & 641.00 & 4.76 & 3.05 \\
\hline 2014/DOLP VAR-3 & 104.33 & 37.97 & 12.03 & 9.73 & 5.59 & 2.07 & 0.23 & 475.00 & 6.62 & 3.14 \\
\hline 2014/DOLP VAR-4 & 64.33 & 36.50 & 9.20 & 8.17 & 12.10 & 1.85 & 0.46 & 883.00 & 4.02 & 3.55 \\
\hline BCDB-10 & 98.67 & 15.62 & 11.93 & 10.16 & 10.99 & 3.79 & 0.60 & 613.00 & 13.66 & 8.38 \\
\hline BCDB-20 & 50.00 & 22.13 & 11.63 & 11.23 & 11.76 & 2.76 & 0.89 & 598.00 & 12.27 & 7.34 \\
\hline BCDB-2 & 92.67 & 16.31 & 8.35 & 7.91 & 11.27 & 3.34 & 0.90 & 976.00 & 6.58 & 6.43 \\
\hline BCDB-5 & 107.33 & 28.94 & 13.38 & 12.64 & 7.37 & 2.52 & 0.82 & 882.00 & 7.15 & 6.31 \\
\hline Swarna Utkrisht & 87.67 & 18.53 & 10.47 & 8.13 & 10.47 & 1.85 & 0.43 & 1004.00 & 5.78 & 5.81 \\
\hline 2016/DOLP VAR-1 & 107.00 & 30.07 & 13.70 & 12.43 & 12.80 & 1.33 & 0.93 & 498.00 & 7.55 & 3.76 \\
\hline 2016/DOLP VAR-2 & 111.67 & 20.08 & 10.20 & 8.07 & 14.66 & 1.79 & 0.84 & 405.00 & 12.37 & 5.01 \\
\hline 2016/DOLP VAR-4 & 94.67 & 28.68 & 11.10 & 10.23 & 13.14 & 2.45 & 0.64 & 594.00 & 12.49 & 7.42 \\
\hline 2016/DOLP VAR-5 & 114.67 & 30.98 & 12.36 & 9.95 & 17.02 & 1.64 & 0.67 & 342.00 & 9.23 & 3.15 \\
\hline 2016/DOLP VAR-6 & 85.00 & 27.54 & 11.17 & 10.59 & 10.67 & 2.12 & 0.61 & 482.00 & 7.53 & 3.62 \\
\hline 2016/DOLP VAR-7 & 114.33 & 28.38 & 10.28 & 9.48 & 12.13 & 1.95 & 0.68 & 666.00 & 4.86 & 3.24 \\
\hline 2016/DOLP VAR-8 & 152.33 & 18.23 & 13.78 & 11.22 & 13.57 & 1.21 & 0.49 & 238.00 & 6.70 & 1.59 \\
\hline 2016/DOLP VAR-9 & 105.33 & 24.71 & 14.92 & 12.45 & 21.49 & 2.03 & 0.68 & 899.00 & 13.83 & 12.43 \\
\hline 2016/DOLP VAR-10 & 115.67 & 18.08 & 12.46 & 10.88 & 12.33 & 0.96 & 0.55 & 600.00 & 5.48 & 3.29 \\
\hline 2016/DOLP VAR-11 & 92.33 & 34.91 & 12.85 & 9.97 & 11.58 & 1.72 & 0.82 & 447.00 & 6.35 & 2.84 \\
\hline Mean & 95.55 & 24.35 & 11.57 & 9.99 & 12.16 & 2.01 & 0.65 & 653.35 & 7.92 & 5.06 \\
\hline Range & $\begin{array}{l}50.00- \\
152.33\end{array}$ & $4.97-37.97$ & $\begin{array}{l}8.35- \\
14.92\end{array}$ & $\begin{array}{l}7.91- \\
12.64\end{array}$ & $\begin{array}{l}5.59- \\
21.49\end{array}$ & $\begin{array}{l}0.96- \\
3.79\end{array}$ & $0.23-0.99$ & $238.00-1004.00$ & $\begin{array}{l}4.02- \\
13.83\end{array}$ & $1.59-12.43$ \\
\hline $\mathrm{CD}$ at $5 \%$ & 3.88 & 7.56 & 2.06 & 1.17 & 1.58 & 0.41 & 0.16 & 64.25 & 0.17 & 0.55 \\
\hline $\mathrm{CV}(\%)$ & 2.48 & 18.76 & 10.95 & 7.16 & 8.05 & 12.35 & 15.18 & 6.16 & 1.35 & 6.91 \\
\hline
\end{tabular}


Table.2 Estimates of genetic parameters of dolichos bean genotypes

\begin{tabular}{lccccc}
\hline Characters & $\mathrm{GCV}^{*}(\%)$ & $\mathrm{PCV}^{*}(\%)$ & GCV:PCV* & $\begin{array}{c}\text { Heritability }(\%) \text { in } \\
\text { broad sense }\end{array}$ & $\begin{array}{c}\text { Genetic advance as } \\
(\%) \text { of mean }\end{array}$ \\
\hline Days to 50\% flowering & 22.76 & 22.89 & 99.41 & 98.82 & 46.60 \\
Raceme length (cm) & 29.16 & 34.67 & 84.09 & 70.71 & 51.24 \\
Leaf length (cm) & 13.79 & 17.61 & 78.31 & 79.66 & 22.25 \\
Leaf width (cm) & 14.18 & 15.89 & 89.25 & 90.82 & 26.07 \\
Pod length (cm) & 25.32 & 26.57 & 95.30 & 85.96 & 49.71 \\
Pod diameter (cm) & 30.57 & 32.97 & 92.72 & 81.11 & 58.39 \\
Pod thickness (cm) & 31.47 & 34.94 & 90.06 & 97.36 & 58.38 \\
Number of pods per plant & 37.42 & 37.92 & 98.67 & 99.88 & 76.06 \\
Pod weight (g) & 39.10 & 39.12 & 99.94 & 98.25 & 80.49 \\
Yield per plant (kg) & 51.82 & 52.28 & 99.12 & & 105.81 \\
\hline
\end{tabular}

${ }^{*} \mathrm{GCV}=$ Genotypic coefficient of variation

${ }^{*} \mathrm{PCV}=$ Phenotypic coefficient of variation

*GCV: PCV (\%) = Ratio of the genotypic coefficient of variation and phenotypic coefficient of variation

Table.3 Genotypic and phenotypic correlations and direct effects of ten characters both at phenotypic and genotypic levels on pod yield/plant

\begin{tabular}{|c|c|c|c|c|}
\hline Characters & $\begin{array}{c}\text { Genotypic correlation } \\
\text { coefficients }\end{array}$ & $\begin{array}{c}\text { Phenotypic correlation } \\
\text { coefficients }\end{array}$ & $\begin{array}{l}\text { Direct effects at } \\
\text { phenotypic level }\end{array}$ & $\begin{array}{l}\text { Direct effects at } \\
\text { genotypic level }\end{array}$ \\
\hline Days to $50 \%$ flowering & -0.15 & -0.15 & -0.05 & -0.07 \\
\hline Raceme length (cm) & -0.28 & -0.22 & -0.02 & -0.06 \\
\hline Leaf length $(\mathrm{cm})$ & 0.32 & 0.25 & 0.03 & -0.06 \\
\hline Leaf width (cm) & 0.32 & 0.28 & 0.09 & 0.21 \\
\hline Pod length $(\mathrm{cm})$ & $0.45^{*}$ & $0.42^{*}$ & 0.07 & 0.11 \\
\hline Pod diameter $(\mathrm{cm})$ & $0.48^{*}$ & $0.45^{*}$ & 0.08 & 0.09 \\
\hline Pod thickness $(\mathrm{cm})$ & 0.17 & 0.15 & 0.01 & -0.01 \\
\hline Number of pods per plant & $0.58^{* *}$ & $0.59^{* *}$ & 0.58 & 0.54 \\
\hline Pod weight $(\mathrm{g})$ & $0.74^{* *}$ & $0.74^{* *}$ & 0.69 & 0.67 \\
\hline
\end{tabular}

Pod weight $(\mathrm{g})$

,** significant at $\mathrm{P} \leq 0.05$ or $\mathrm{P} \leq 0.01$, respectively.

Residual effect at phenotypic level: 0.04481 ; Residual effect at genotypic level: 0.03705 
Table.4 Cluster classification of twenty three genotypes of dolichos bean

\begin{tabular}{|c|c|c|c|}
\hline $\begin{array}{l}\text { Cluster with the number of } \\
\text { genotype in parantheses }\end{array}$ & \multicolumn{3}{|c|}{ Name of the genotype } \\
\hline $\begin{array}{l}\text { Cluster I } \\
\text { Cluster II }\end{array}$ & \multicolumn{3}{|c|}{$\begin{array}{l}\text { BCDB-10, BCDB-20, 2013/DOLP VAR-3, 2014/DOLP VAR-1, 2014/DOLP VAR-2, 2014/DOLP } \\
\text { VAR-3, 2016/DOLP VAR-2, 2016/DOLP VAR-4, 2016/DOLP VAR-1, 2016/DOLP VAR-5, } \\
\text { 2016/DOLP VAR-6, 2016/DOLP VAR-7, 2016/DOLP VAR-8, 2016/DOLP VAR-10, 2016/DOLP } \\
\text { VAR-11 } \\
\text { BCDB-2, BCDB-5, Swarna Utkrisht, 2016/DOLP VAR-9, 2013/DOLP VAR-2, 2014/DOLP VAR- } \\
\text { 4, 2013/DOLP VAR-4, 2013/DOLP VAR-1 }\end{array}$} \\
\hline \multicolumn{4}{|c|}{ Table.5 Inter and intra cluster distances of 23 genotypes of dolichos bean } \\
\hline Clusters & & & II \\
\hline I & & & 89.80 \\
\hline II & & & 88.85 \\
\hline \multicolumn{4}{|c|}{ Table.6 Cluster means of 23 genotypes of dolichos bean } \\
\hline Characters & Cluster I & Cluster II & $\begin{array}{c}\% \text { Contribution towards } \\
\text { divergence }\end{array}$ \\
\hline Days to $50 \%$ flowering & 87.47 & 100.31 & 0.72 \\
\hline Raceme length $(\mathrm{cm})$ & 24.57 & 24.34 & 1.09 \\
\hline Leaf length $(\mathrm{cm})$ & 10.88 & 11.86 & 0.00 \\
\hline Leaf width $(\mathrm{cm})$ & 9.27 & 10.38 & 0.72 \\
\hline Pod length $(\mathrm{cm})$ & 11.62 & 12.22 & 0.16 \\
\hline Pod diameter $(\mathrm{cm})$ & 1.90 & 2.10 & 0.00 \\
\hline Pod thickness (cm) & 0.58 & 0.72 & 0.00 \\
\hline Number of pods per plant & 678.50 & 593.50 & 1.45 \\
\hline Pod weight (g) & 7.52 & 7.97 & 39.86 \\
\hline Yield per plant $(\mathrm{kg})$ & 4.81 & 4.89 & 50.36 \\
\hline
\end{tabular}


Int.J.Curr.Microbiol.App.Sci (2017) 6(12): 381-395

Table.7 Results of principal component analysis (PCA) for six quantitative characters contributing to divergence (Eigen values >1)

\begin{tabular}{|c|c|c|c|}
\hline Principal component (PC) & Eigenvalue $(\%)$ & $\%$ Variance & $\%$ Cumulative variance \\
\hline \multicolumn{4}{|c|}{ Eigenvalues and variance accounted for $(\%)$ by PCA based on correlation matrix } \\
\hline $\mathrm{PC} 1$ & 43190.7724 & 98.94 & 98.94 \\
\hline $\mathrm{PC} 2$ & 378.9781 & 0.87 & 99.81 \\
\hline PC3 & 57.7642 & 0.13 & 99.94 \\
\hline PC4 & 15.6342 & 0.04 & 99.98 \\
\hline PC5 & 5.8122 & 0.01 & 99.99 \\
\hline PC6 & 2.6915 & 0.01 & 100.00 \\
\hline
\end{tabular}

Table.8 Principal Component analysis for dolichos bean traits

\begin{tabular}{|c|c|c|c|c|c|c|}
\hline Variables & PC1 & $\mathrm{PC} 2$ & PC3 & PC4 & PC5 & PC6 \\
\hline \multicolumn{7}{|c|}{ Factor loadings due to PCs with eigenvalues greater than 1} \\
\hline Days to $50 \%$ flowering & -0.049819 & 0.992846 & 0.094206 & -0.004531 & 0.017601 & -0.049900 \\
\hline Raceme length $(\mathrm{cm})$ & -0.004648 & -0.097491 & 0.978428 & 0.150351 & -0.001926 & -0.102177 \\
\hline Leaf length $(\mathrm{cm})$ & -0.002369 & 0.033464 & 0.043665 & 0.190687 & 0.156761 & 0.672046 \\
\hline Leaf width $(\mathrm{cm})$ & -0.001280 & 0.018514 & 0.045843 & 0.160951 & 0.194945 & 0.620783 \\
\hline Pod length $(\mathrm{cm})$ & -0.001191 & 0.027432 & -0.070791 & 0.522175 & -0.838946 & 0.069350 \\
\hline Pod diameter $(\mathrm{cm})$ & 0.000923 & -0.006563 & -0.017443 & 0.037883 & 0.128429 & -0.183381 \\
\hline
\end{tabular}


Fig.1 Dendrogram of 23 genotypes of dolichos bean following Ward's method Dendrogram using Average Linkage (Between Groups)

Rescaled Distance Cluster Combine

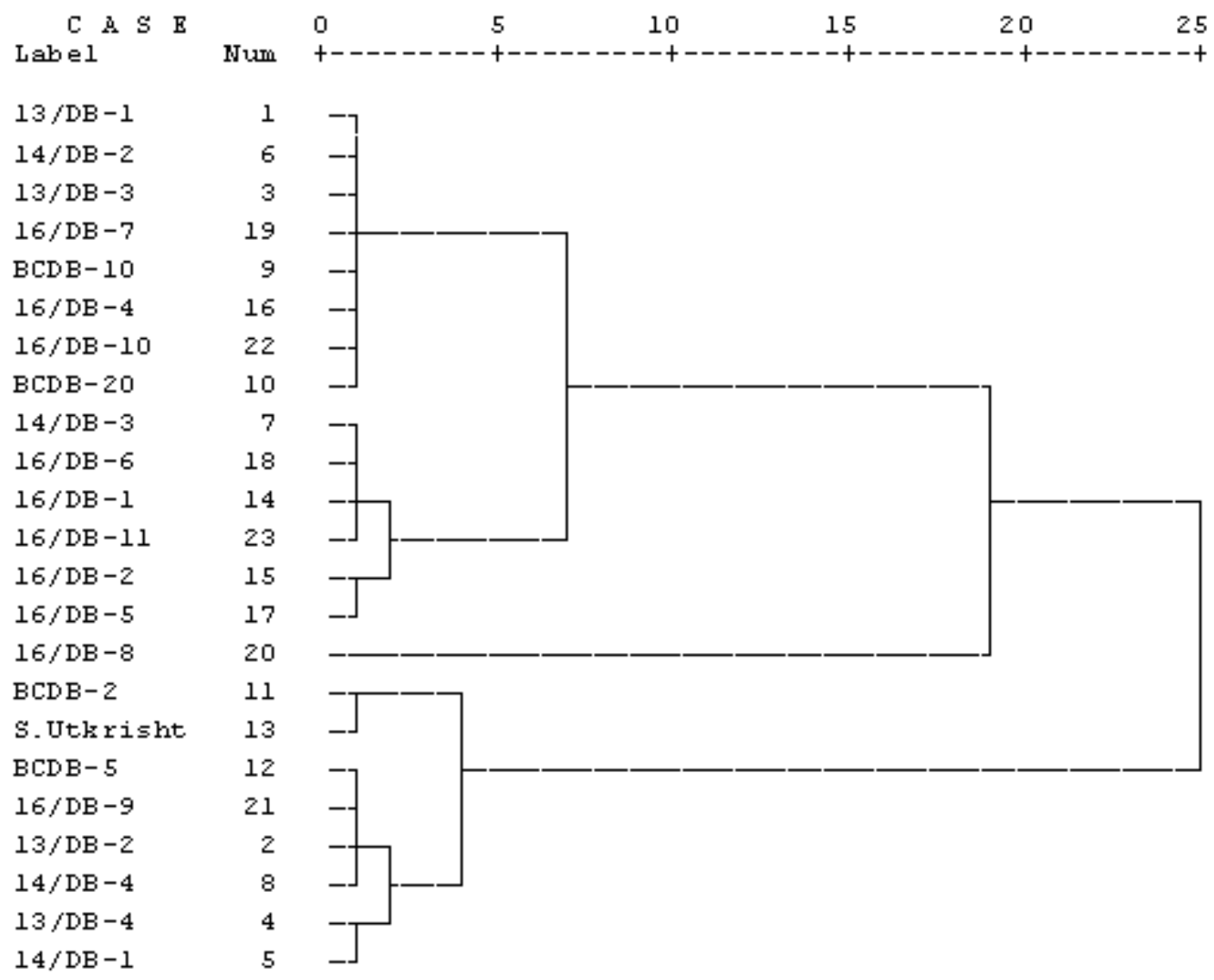


Fig.2 Scatter diagram of regression factor scores for the first two components produced by principal component analysis

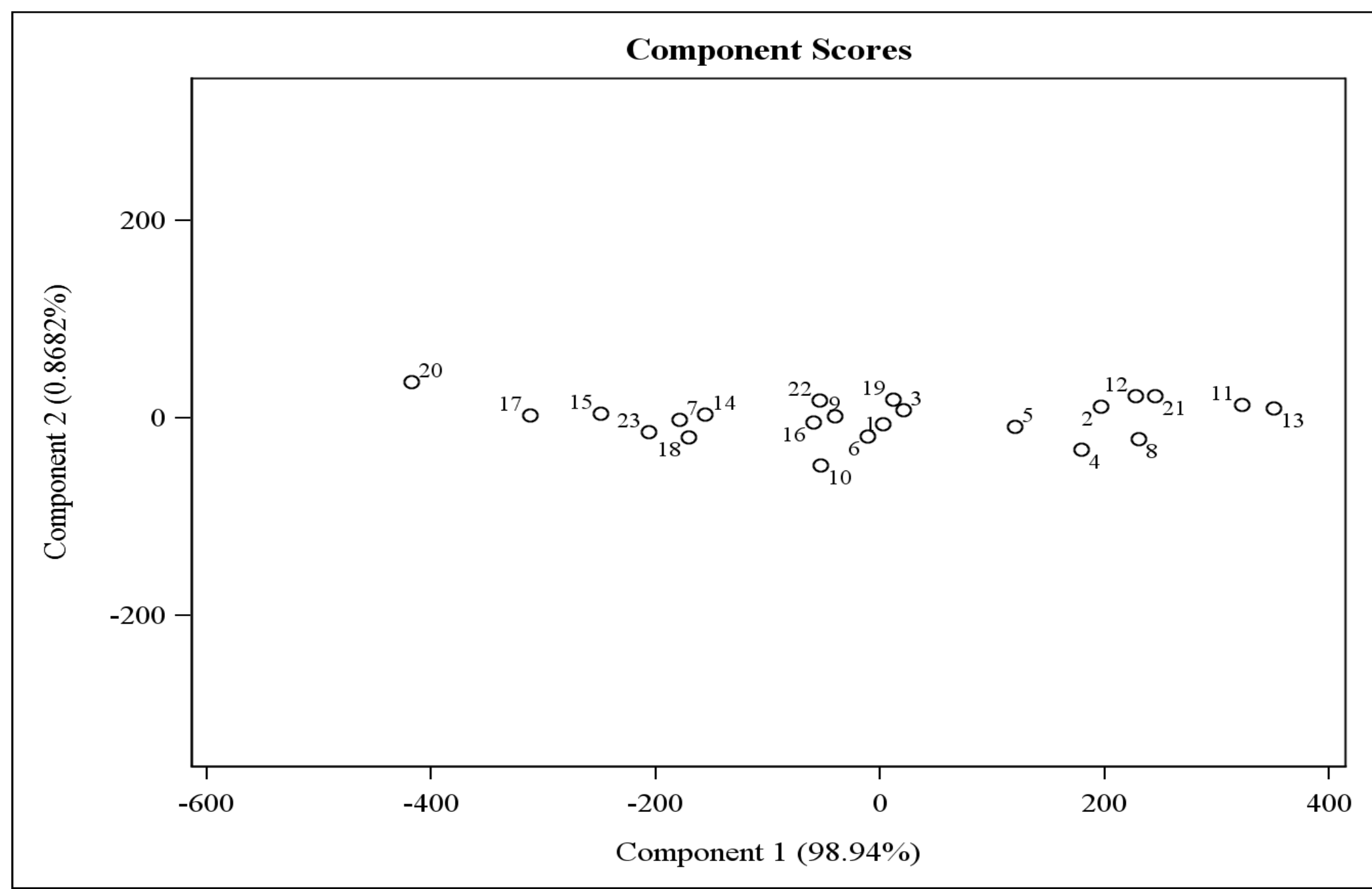

*Genotype 1: 2013/DOLP VAR-1, 2: 2013/DOLP VAR-2, 3: 2013/DOLP VAR-3, 4: 2013/DOLP VAR-4, 5: 2014/DOLP VAR-1, 6: 2014/DOLP VAR-2, 7: 2014/DOLP VAR-3, 8: 2014/DOLP VAR-4, 9:BCDB-10, 10: BCDB-10, 11: BCDB-2, 12: BCDB-5, 13: Swarna Utkrist, 14: 2016/DOLP VAR-1, 15: 2016/DOLP VAR-2, 16: 2016/DOLP VAR-4, 17: 2016/DOLP VAR-5,18: 2016/DOLP VAR-6, 19: 2016/DOLP VAR-7, 20: 2016/DOLP VAR-8, 21: 2016/DOLP VAR-9, 22: 2016/DOLP VAR-10, 23: 2016/DOLP VAR-11 
Residual effects were very low at phenotypic (0.0448) and genotypic (0.03705) levels suggesting inclusion of maximum pod yield influencing characters in the present analyses.

The character number of pods per plant and pod weight showed the highest positive direct effects on pod yield per plant thereby indicating a true correlation and could be taken as major components for the improvement of yield (Table 3). Dahiya et al., (1991) and Tikka et al., (2003) reported that pods per plant had the highest direct effect on pod yield.

\section{Genetic divergence through multivariate analysis and PCA}

Genetic diversity has been considered as an important factor in discriminating the genotypes for genetically diverse parents for obtaining high yielding lines for efficient and successful hybridization programme. Multivariate analysis using Mahalanobis's $\mathrm{D}^{2}$ statistic has been found to be a potential biometrical tool in quantifying the degree of divergence in germplasm collections of crop plants. Genetic divergence analysis therefore, was attempted to identify suitable parents among 23 genotypes of dolichos bean.

Assessment of genetic diversity was made based on the data recorded for pod yield and component characters in 23 genotypes using Mahalanobis's $D^{2}$ statistic analysis. The 23 genotypes were grouped into 2 clusters based on the relative magnitude of $\mathrm{D}^{2}$ values (Table 4). The distribution pattern of genotypes into clusters indicated that cluster I had the largest comprising of 15 genotypes followed by cluster II with 8 genotypes.

The estimates of intra- and inter cluster values represented by $\mathrm{D}^{2}$ values (Table 5). The maximum intra cluster distance was observed in cluster II (89.85) and minimum in cluster I
(88.69). The minimum inter-cluster distance indicated close relationship among the genotypes of these clusters and had a maximum of similar gene complexes among them. The maximum inter-cluster distance suggested wide diversity among the genotypes between the groups. The promising genotypes from these clusters could be utilized as potential parents and crossing between these genotypes would result in heterotic expression for yield component traits. Kalloo et al., (1980) suggested that the crosses between selected varieties from widely separated clusters are most likely to give desirable recombinants. The absence of relationship between genetic diversity and geographical distance indicates that forces other than geographical origin such as exchange of genetic stock, genetic drift, spontaneous mutation, natural and artificial selection are responsible for genetic diversity. Therefore, selection of genotypes for hybridization should be based on genetic diversity rather than geographic divergence (Mehta et al., 2009). Therefore, the selection of genotypes for hybridization should be based on genetic divergence rather than geographic diversity.

Cluster means for different characters showed considerable differences between the clusters for all the characters (Table 6). The genotypes of cluster I recorded the superior performance for number of pods per plant whereas the genotypes of cluster II showed superior performance for rest of the characters. Intercrossing the elite genotypes from these clusters could be suggested to generate wide range of variability followed by effective selection for improvement of pod yield. The relative contribution of different plant characters to the total genetic divergence estimated by $\mathrm{D}^{2}$ analysis indicated that pod yield per plant contributed the maximum $(50.36 \%)$ towards genetic divergence followed by pod weight $(39.86 \%)$ (Table 6$)$. 
Apart from the high divergence, the performance of genotypes and the characters with maximum contribution towards divergence should also be given consideration which appears as desirable for inclusion for improvement in dolichos bean. Selection of genotypes for hybridization should be based on genetic diversity rather than geographic divergence as observed in dolichos bean. In spite of huge diversity among the genotypes, relatively small number of clusters indicated either common character constellation or mutual balancing of characters among the genotypes. Biju et al., (2001) observed the maximum contribution of pod yield towards divergence in field bean.

The PCA was performed to obtain a simplified view of the relationship between the characters days to $50 \%$ flowering, raceme length, leaf length, leaf width, pod length and pod diameter which explained $100 \%$ contribution towards divergence than other remaining traits, and variable loadings for components PC1 (days to 50\% flowering), PC2 (raceme length), PC3 (leaf length), PC4 (leaf width), PC5 (pod length) and PC6 (pod diameter) (Table 7). These components were chosen because their eigenvalues exceeded 1.0 and explained $100.0 \%$ of total variance. The first component (PC1) explained $98.94 \%$ of total accounted for variance in which a decrease in days to $50 \%$ flowering leads to decrease in raceme length, leaf length, leaf width, and pod length (Table 8). The second component (PC2) explained an additional $0.87 \%$ of the variance in which an increase in days to $50 \%$ flowering was associated with increased leaf length, leaf width and pos weight along with decreased raceme length. There are no clear guidelines to determine the importance of a trait coefficient for each principal component. Johnson and Wichern (1988) regard a coefficient that is greater than half of the coefficient, divided by the square root of the standard deviation of the eigenvalue of the respective principal component, as significant. Genotypes in close proximity are perceived as being similar in PCA, whereas accessions that are further apart are more diverse.

High diversity occurred among genotypes along with strong relationships (Figure 1). The scattered diagram (Figure 2) indicated genotypes 2014/DOLP VAR-4, 2016/DOLP VAR-5 and 2016/DOLP VAR-8 have distinct differences of genotypic characters and belong to farthest distances from the other genotypes. The remainder of the genotypes has similar features and formed a separate cluster.

Based on principal component analysis and average values the genotypes 2016/DOLP VAR-9, BCDB-10 and 2016/DOLP VAR-4 possessed the optimum combination of all variables and these genotypes should be considered for future use in development of improved lines of dolichos bean.

\section{References}

Biju, M.G., Prasanna, K.P., and Rajan, S. 2001. Genetic divergence in hyacinth bean. Vegetable Science. 28(2): 163164.

Borah, P., and Shadeque, A. 1992. Studies on genetic variability of common Dolichos bean. Indian Journal of Horticulture. 49:270-273.

Burton, G.S. 1952. Quantitative inheritance in grasses. Proceedings of 6th Int. Grassland Congress. 1: 277-283.

Chattopadhyay, A., and Dutta, S. 2010. Characterization and identification of selection indices of pole type dolichos bean. Vegetable Crops Research Bulletin. 73: 33-45.

Chattopadhyay, A., Dutta, S., Bhattacharya, I., Karmakar, K., and Hazra, P. 2007. Dolichos bean, In: Technology for 
Vegetable Crop Production, Published by All India Coordinated Research Project on Vegetable Crops. BCKV, Nadia, West Bengal, India, pp. 218-230. Dahiya, M.S., Pandita, M.L., and Vashistha, R.N. 1991. Correlation and path analysis studies in sem (Dolichos lablab var. lignosus L.). Haryana Journal of Horticultural Sciences. 20(1-2): 134138.

Das I., Shende V.D., Seth T., Yadav Y., and Chattopadhyay A. 2015. Genetic analysis and interrelationships among yield attributing traits in pole and bush type dolichos bean (Lablab purpureus L.). Journal Crop and Weed. 11(2): 7277.

Dewey, D.R., and Lu, H.K. 1959. A correlation and path co-efficient analysis of component of crested wheat grass production. Agronomy Journal. 51: 515-518.

Ganesh, B.N. 2005. Genetic variability and divergence studies by $\mathrm{D}^{2}$ statistics and RAPD analysis in field bean (Lablab purpureus L. Sweet). M. Sc. (Agri.) Thesis, Acharya N. G. Ranga Agricultural University (Andhra Pradesh).

Hanson, C.H., Robinson, H.F., and Comstock, R.E. 1956. Biometrical studies of yield in segregating population of Korean lespedza. Agronomy Journal. 48: 268272.

Johnson, H.W., Robinson, H.F., and Comstock, R.W. 1955. Estimation of genetic and environmental variability in soybean. Agronomy Journal. 47: 447-483.

Johnson, R.A., and D.W. Wichern. 1988. Applied multivariate statistical analysis. Prentice-Hall, Englewood Cliffs, N.J.

Kabir, J., and Sen, S. 1987. Studies on genetic variability and heritability in dolichos bean. Journal American Society of Agronomy. 8(1): 141-144.
Kalloo, G., Singh, V.P., Dudi, B.S., and Pratap P.S. 1980. Analysis of variation and genetic divergence in garden peas (Pisum sativum L.). Haryana Agricultural University Journal Research. 10:540-46.

Kaushik, N., Kumar, K., Kumar, S., Kaushik, N., and Roy, S. 2007. Genetic variability and divergence studies in seed traits and oil content of Jatropha (Jathropha curcas L.) accessions. Biomass and Bioenergy. 31:497-502.

Lush, J.L. 1949. Heritability of quantitative characters in farm animals. Proceedings of 8th Congress of Genetics and Heredity. 35: 356-375.

Mahalanobis, P.C. 1936. On the generalized distance in statistics. Proceedings of the National Institute of Sciences (Calcutta). 2: 49-55.

Mehta, N., and Asati, B.S. 2008. Genetic divergence for fruit characters in tomato (Lycopersicon esculentum Mill.). Agricultural Science Digest. 28(2):141142.

Mohan, N., Aghora, T.S., and Wani, M.A. 2014. Studies on genetic variability in dolichos bean (Lablab purpureus L.). Journal of Horticulture Science. 9(1): $82-85$.

Panse, V.G. 1957. Genetics of quantitative characters in relation to plant breeding. Indian Journal of Genetics and Plant Breeding. 17: 318-328.

Patil, A.B., Desai, D.T., Patil, S.A., and Patil, S.S. 2011. Heterosis for yield and its components in vegetable lablab bean (Lablab purpureus l.) Legume Research. 35(1): 18-22.

Peter, K.V., and Kumar, P.T. 2008. Genetics and Breeding of Vegetable Crops. Indian Council of Agricultural Research, New Delhi, pp. 231-234.

Rao, C.R. 1952. Advance statistical methods in biometrics. John Willey and Sons Pvt. Ltd., New York. 
Sanghi, A.K., Bhatnagar, M.P., and Sharm, S.K. 1964. Genotypic and phenotypic variability in yield and other quantitative character in guar. Indian Journal of Genetics and Plant Breeding. 29: 164167.

Singh, R.B., Gupta, M.P., Mor, B.R. and Jain, D.K. 1968. Variability and correlation studies on yield and quality characters in hirsutum cotton. Indian Journal of Genetics. 28: 216-22.

Tikka, S.B.S., Chauhan, R.M., Parmar, L.D., and Solanki S.D. 2003. Character interrelationship in grain type Indian bean. Advances in Arid Legumes Research. pp. 136-139.

Uddin, S. and Newaz, M.A. 1997. Genetic parameters and the association among flower and pod characterstics of hyacinth bean (Lablab purpureus L.). Legume Research. 50: 82-86.

Upadhyay, D., and Mehta, N. 2010. Biometrical studies in Dolichos Bean (Dolichos lablab L.) for Chattisgarh Plains. Journal of Agricultural Sciences. 1 (4): 441-447.

Verma, A.K., Jyothi, K., and Rao, A.V.D. 2015. Variability and character association studies in dolichos bean (Lablab purpureus L.) genotypes. Indian Journal of Agricultural Research. 49 (1): 46-52.

Ward, J.H. 1963. Hierarchical grouping to optimize an objective function. Journal of the American Statistical Association. 58: 236-244.

\section{How to cite this article:}

Niharika Jyotirekha Nayak, Praveen Kumar Maurya, Anirban Maji, Soumitra Chatterjee, Amit Ranjan Mandal and Arup Chattopadhyay. 2017. Estimation of Genetic Parameters and Selection of Parents for Hybridization in Dolichos Bean [Dolichos lablab L.]. Int.J.Curr.Microbiol.App.Sci. 6(12): 381-395. doi: https://doi.org/10.20546/ijcmas.2017.612.046 